Agrica, 5 (1): 44-56 (2012)

@Fakultas Pertanian Universitas Flores

ISSN: 1979-0368

Ende NTT-Indonesia

\title{
PENINGKATAN KETERSEDIAAN DAN SERAPAN NPK SERTA HASIL TANAMAN JAGUNG BISI-16 MELALUI INOKULASI MIKORIZA DAN PUPUK NPK PADA ALFISOL
}

\author{
Yovita Yashinta Boly \\ Vytayovieeta@gmail.com
}

\begin{abstract}
This study is to investigate the influence of mycorhiza isolate with different origin rhizosphere and fertilizer NPK with different dosage to the available and absoption of NPK as well as the corn yield and to determine the optimum dosage of fertilizer NPK in each mycorrhiza isolate with different origin rhizosphere and availability and uptake of NPK and corn yields and to determine the optimum dosage of fertilizer NPK for each different origin rhizosphere ofisolates mycorrhizal inoculated against corn yield. This study used complete Randomized Block Design (CRBD) consisting of 20 treatment combinations with three replications, they are without mycorrhiza and without fertilizer $(\mathrm{m} 0 \mathrm{p} 0)$ without mycorrhiza $+25 \%$ dose of NPK (m0p1) without mycorrhiza $+50 \%$ dose of NPK (m0p2) without mycorrhiza $+75 \%$ dose of NPK $(\mathrm{mlp} 3)$ without mycorrhiza $+100 \%$ dose of NPK (m1p4), origin rhizosphere mycorrhiza of the of corn plants $+100 \%$ dose of NPK (m2p2) without fertilizer $(\mathrm{mlp} 0)$ mycorrhiza origin of the rhizosphere of corn plants $+25 \%$ dose of NPK (m1p1) mycorrhiza origin rhizosphere of plants corn $+50 \%$ dose of NPK (m1p2) origin rhizosphereof mycorrhiza the corn plants+ $75 \%$ dose of NPK (m1p3), mycorrhiza origin of the rhizosphere of corn plants $+100 \%$ dose of NPK (m1p4), origin rhizosphere of mycorrhiza the cassava + without fertilizers $(\mathrm{m} 2 \mathrm{p} 0)$, origin of mycorrhiza of the cassava + $25 \%$ dose of NPK $(\mathrm{m} 2 \mathrm{p} 1)$, origin rhizosphere of mycorrhiza of cassava $+50 \%$ dose of NPK (m2p2), origin rhizosphere of mycorrhiza of cassava $+75 \%$ dose of NPK (m2p3), origin rhizosphere of mycorrhiza of cassava $+100 \%$ dose of NPK $(\mathrm{m} 2 \mathrm{p} 4)$ mycorrhizal from serpong + without fertilizer $(\mathrm{m} 3 \mathrm{p} 0)$, mycorrhiza from serpong $+25 \%$ dose of NPK $(\mathrm{m} 3 \mathrm{p} 1)$, mycorrhiza from serpong $+50 \%$ dose of NPK $(\mathrm{m} 3 \mathrm{p} 2)$, mycorrhiza from serpong + $75 \%$ dose of NPK (m3p3), mycorrhiza from serpong $+100 \%$ dose of NPK (m3p4). The results showed that mycorrhiza treatment and dosage of fertilizer NPK can increase the availability of NPK, NPK uptake, dry weight of plant and dry weight of seed. Regression test showed the optimum dosage of NPK on m0 treatment cannot be determined because it is linear, while the optimum dosage of NPK fertilizer on the treatment of inoculated mycorrhizal of origin rhizosphere of corn (m1) is $50.66 \%$ the recommended dose, in the treatment of native mycorhiza rhizosphere of cassava $(\mathrm{m} 2)$ is $45.11 \%$, and the treatment of mycorrhiza from serpong (m3) is $46.10 \%$.
\end{abstract}

Keywords: corn, mycorrhiza, NPK absorption. 
Yovita: Peningkatan ketersediaan dan serapan NPK serta hasil tanaman jagung Bisi-16 melalui inokulasi mikoriza dan pupuk NPK pada Alfisol

\section{LATAR BELAKANG}

Lahan-lahan Pertanian di Pulau Timor sebagian besar tergolong lahan marginal dengan tingkat kesuburan tanah rendah sehingga menyebabkan ketersediaan pangan secara kuantitas dan kualitas sulit terpenuhi (Duaja, 2006). Hal ini disebabkan ketersediaan hara dalam tanah juga menjadi faktor pembatas produksi pertanian. Jenis tanah yang banyak tersebar di Pulau Timor adalah Alfisol. Tanah ini dicirikan dengan kandungan $\mathrm{C}$ organik rendah, $\mathrm{pH}$ tinggi, $\mathrm{N}$ total rendah, $\mathrm{P}$ tersedia sangat rendah dan Ca tinggi (Kasim, 2005).

Menyikapi kondisi tersebut, dibutuhkan suatu tindakan yang mampu mengefisiensikan penyerapan hara oleh tanaman. Dalam hal ini, manipulasi daerah perakaran dengan memanfaatkan mikoriza dapat menjadi alternatif pemecahan masalah yang tepat. Mikoriza terbentuk karena informasi spesifik yang dihasilkan oleh akar tanaman untuk menarik cendawan agar dapat bersimbiosis dengannya.

Sejumlah besar hasil penelitian membuktikan bahwa mikoriza dapat meningkatkan penyerapan hara terutama hara P. Hasil penelitian Zulaikha dan
Gunawan (2006) membuktikan bahwa interaksi antara mikoriza dengan pupuk fosfat meningkatkan pertumbuhan tanaman yang ditandai dengan meningkatnya laju tumbuh tanaman cabai merah pada Alfisol.

Banyak hasil penelitian menunjukkan indikasi meningkatnya perpindahan $\mathrm{N}$ dari tanah ke tanaman yang relatif lebih tinggi pada tanaman yang berasosiasi dengan mikoriza vesikula arbuscular (MVA) dari pada tanaman yang tidak berasosiasi dengan MVA (Barea, dkk, 1989; dalam Bako,dkk. 2009). Lebih lanjut dijelaskan bahwa MVA dapat meningkatkan serapan hara tanaman, terutama hara yang mobilitasnya rendah di dalam tanah. Nitrat di dalam tanah merupakan bagian utama dari cadangan utama mineral $\mathrm{N}$, yang ditranspor ke akar tanaman oleh aliran massa, sehingga peranan MVA tidak banyak berpengaruh terhadap perolehan $\mathrm{N}$ dalam bentuk nitrat bagi tanaman (Harley dan Smith, 1983; Read, dkk., dalam Bako,dkk. 2009). Sebalikya, MVA menjadi berperan penting dalam perolehan $\mathrm{N}$ bagi tanaman apabila sebagian besar mineral $\mathrm{N}$ dalam tanah berbentuk ammonium, yang mempunyai 
Yovita: Peningkatan ketersediaan dan serapan NPK serta hasil tanaman jagung Bisi-16 melalui inokulasi mikoriza dan pupuk NPK pada Alfisol

sifat kurang mobil karena amonium teradsorpsi oleh mineral lempung (Nommik dan Wahtras, 1982 dalam Bako,dkk. 2009).

Hasil penelitian Bako,dkk 2009 membuktikan bahwa pada perlakuan sumber isolat mikoriza, kadar K-tersedia tanah pada perlakuan tanpa mikoriza relatif lebih tinggi dibanding semua perlakuan isolat mikoriza yang dicobakan. Hal tersebut memperlihatkan peranan mikoriza dapat meningkatkan laju serapa hara termasuk K. Kadar K tersedia yang rendah pada semua perlakuan isolat mikoriza mengindikasikan tingginya laju penyerapan $\mathrm{K}$ oleh tanaman selama masa pertumbuhannya sehingga kadar $\mathrm{K}$ tersedia tanah yang tersisa di akhir penelitian menjadi relatif rendah.

Mikoriza dapat berasosiasi dengan hampir sebagian besar tanaman pangan termasuk jagung. Tanaman jagung memiliki nilai ekonomis yang cukup tinggi. Menurut (Najiyati, 1992) dalam setiap 100 gram biji jagung terdapat 335 kalori; 9,2 gram protein; 3,9 gram lemak dan 7,3 gram karbohidrat. Potensi lahan kering untuk peningkatan dan pengembangan jagung di Pulau Timor cukup luas dan tersebar hampir di seluruh Kabupaten, oleh karena itu Pulau Timor (Propinsi Nusa Tenggara Timur) secara nasional ditargetkan sebagai salah satu daerah penghasil jagung. Mengingat keuntungan yang dimiliki oleh mikoriza terutama dalam kemampuannya untuk meningkatkan penyerapan hara maka penambahan mikoriza ke dalam tanah diharapkan dapat meningkatkan hasil tanaman jagung baik dalam kualitas maupun kuantitas.

\section{METODE PENELITIAN}

\section{Tempat Dan Waktu Penelitian}

Penelitian ini bertempat di Desa Nevon, Kelurahan Liliba dan laboratorium Mikrobiologi Dan Laboratorium Kimia Tanah yang akan dilaksanakan selama bulan Agustus 2012 sampai Februari 2013.

\section{Bahan dan Alat}

Bahan-bahan yang digunakan dalam penelitian ini adalah : Alfisol Oebelo, pupuk N, P K, benih jagung varietas Bisi 16, mikoriza indigen NTT yaitu mikoriza asal rhisosfer Jagung Suanae $0 \geq 150 \mu \mathrm{m}$ (orange), mikoriza asal rhisosfer ubi kayu Oesapa $0 \geq 45 \mu \mathrm{m}$ (hitam), dan mikoriza asal BPPT Serpong 
Yovita: Peningkatan ketersediaan dan serapan NPK serta hasil tanaman jagung Bisi-16 melalui inokulasi mikoriza dan pupuk NPK pada Alfisol

- Peralatan yang digunakan adalah polybag dengan ukuran $10 \mathrm{~kg}$, papan label perlakuan, timbangan, alat tulis menulis, dan alat-alat analisis laboratorium

\section{Rancangan percobaan}

Penelitian ini menggunakan rancangan faktor tunggal dengan rancangan dasar yaitu rancangan acak kelompok (RAK). Kombinasi perlakuan dari mikoriza $(\mathrm{m} 0, \mathrm{~m} 1, \mathrm{~m} 2, \mathrm{~m} 3$ dan $\mathrm{m} 4)$ serta pupuk NPK (p0, p1, p2, p3 dan p4).

Dengan demikian maka terdapat 20 kombinasi dengan tiga ulangan.

\section{Variabel Pengamatan}

Pengamatan dilakukan dengan data pengamatan destruktif dan non destruktif yang meliputi :N-total tanah (\%), P tersedia tanah (ppm), K-dd (me/100 g), Serapan NPK oleh jaringan tanaman (\%) (metode pengabuan kering), Bobot kering tanaman $\left(\mathrm{g} \mathrm{pot}^{-1}\right)$ dan Bobot biji pipilan kering (g). Sedangkan parameter Penunjang terdiri dari: Kandungan Ntotal, P-tersedia dan K-tersedia tanah awal percobaan sebelum diberi perlakuan.

\section{HASIL DAN PEMBAHASAN}

\section{N- Total tanah}

Dari hasil penelitian menunjukkan bahwa pada perlakuan tanpa mikoriza dan
NPK, kandungan N-total tanah tertinggi terdapat pada perlakuan m0p4 sedangkan $\mathrm{N}$-total tanah terendah terdapat pada perlakuan m0p0. Perlakuan tanpa mikoriza dan dosis pupuk menunjukkan semakin tinggi dosis pupuk yang diberikan akan meningkatkan kandungan N-total tanah. Hal ini disebabkan karena tidak adanya pengaruh mikoriza terhadap penyerapan NPK tanah sehingga tanaman hanya mendapatkan unsur hara yang berasal dari pupuk kimia yang diberikan.

Pada perlakuan mikoriza dan diikuti pemberian pupuk NPK menunjukkan kandungan N-total tanah tertinggi terdapat pada perlakuan m1p1 yang tidak berbeda nyata dengan perlakuan m1p2. Tingginya kandungan $\mathrm{N}$ total tanah pada perlakuan mikoriza dan pupuk, karena mikoriza mempunyai hifa yang sangat halus sehingga memungkinkan hifa dapat menjangkau bagian pori-pori tanah yang paling kecil dan bisa meningkatkan penyerapan air, sehingga mampu membawa unsure hara yang mudah larut dan terbawa oleh liran massa seperti nitrogen sehingga unsur hara tersebut juga meningkat (Subiksa, 2002). Azcon dan Al-Atrash (1997) dalam Subiksa (2002) melaporkan tanaman alfalfa yang 
Yovita: Peningkatan ketersediaan dan serapan NPK serta hasil tanaman jagung Bisi-16 melalui inokulasi mikoriza dan pupuk NPK pada Alfisol

diinokulasi mikoriza menyebabkan terjadinya peningkatan pembentukan bintil akar sedangkan tanaman non kacang-kacangan peranan mikoriza melalui peningkatan serapan hara $\mathrm{N}$ yang terbawa masuk bersama serapan air.

\section{P- Tersedia Tanah}

Data hasil penelitian menunjukkan bahwa inokulasi mikoriza dan dosis pupuk NPK mampu meningkatkan kandungan P-tanah. Pada perlakuan tanpa mikoriza dan dosis pupuk menunjukkan kandungan P-tersedia tanah terendah terdapat pada perlakuan m0p0, sedangkan perlakuan m0p1 tidak berbeda nyata dengan perlakuan m0p2, m0p3 dan m0p4. Pada perlakuan mikoriza dan dosis pupuk menunjukkan kandungan P-tersedia tanah tertinggi pada perlakuan m1p1,m1p2, m1p3 dan m1p4, m2p3 dan m3p2.

Tingginya kandungan $\mathrm{P}$ tanah pada perlakuan mikoriza dan NPK karena dengan adanya mikoriza mampu membentuk polifosfat dalam hifa sehingga mempertahankan konsentrasi $\mathrm{P}$, selain itu dengan hifanya mikoriza mampu memperluas permukaan kontak dengan sumber $\mathrm{P}$ yang lebih besar dibandingkan dengan akar tanaman, dan mikoriza menghasilkan enzim fosfatase sehingga meningkatkan kelarutan hara $\mathrm{P}$ (Baon, 1997). Mosse (1973) dalam Widiastuti (2002) melaporkan pengaruh yang merugikan tingkat $\mathrm{P}$ tanah yang tinggi pada simbiosis mikoriza. Tingginya $\mathrm{P}$ tanah menghambat mikoriza secara langsung dengan menekan perkecambahan spora dan pertumbuhan hifa dari spora yang berkecambah, sehingga peran mikoriza tidak berfungsi untuk menyumbangkan P-tersedia tanah.

\section{K- dd}

Berdasarkan hasil analisis varians, perlakuan tanpa mikoriza dan dosis pupuk NPK, kandungan K-dd terendah terdapat pada m0p0 (tanpa mikoriza dan tanpa pupuk) dengan rerata $0,127 \mathrm{me} / 100 \mathrm{~g}$. Perlakuan mikoriza dan dosis pupuk NPK menunjukkan K-dd terendah terdapat pada perlakuan $\mathrm{m} 2 \mathrm{p} 0, \mathrm{~m} 2 \mathrm{p} 4, \mathrm{~m} 3 \mathrm{p} 0$, dan m3p4 sedangkan K-dd tertinggi terdapat pada perlakuan m1p2 dan m1p2 (masingmasing dengan nilai 0,280 dan 0,300 me/100 gr).

Subiksa (2002) menyatakan bahwa pengambilan air oleh tanaman yang bermikoriza membawa unsur hara yang mudah larut dan terbawa oleh aliran massa sehingga dapat meningkatkan $\mathrm{K}$ tersedia tanah. Hifa mikoriza dengan 
Yovita: Peningkatan ketersediaan dan serapan NPK serta hasil tanaman jagung Bisi-16 melalui inokulasi mikoriza dan pupuk NPK pada Alfisol

ukuran yang lebih halus dari diameter bulu-bulu akar memungkinkan hifa bisa menyusup ke dalam pori-pori tanah yang kecil, dengan diameter yang lebih halus hifa ini memiliki luas permukaan lebih besar sehingga bisa menyerap air pada kondisi kadar air tanah sangat rendah. Hifa berfungsi sebagai jembatan yang menghubungkan akar dengan tanah, sehingga lapisan tipis air dan alirannya ke akar dapat diatur dan terpelihara.

\section{Analisis Jaringan Tanaman}

\section{N Jaringan Tanaman}

Perlakuan tanpa mikoriza dan dosis pupuk NPK menunjukkan kandungan N jaringan tertinggi $1,85 \%$ pada perlakuan tanpa mikoriza dan pupuk 100\% NPK (m0p4), sedangkan $\mathrm{N}$ jaringan terendah $1,40 \%$ terdapat pada perlakuan tanpa mikoriza dan tanpa pupuk (m0p0).

Perlakuan mikoriza dan dosis pupuk NPK memberikan pengaruh $\mathrm{N}$ jaringan tertinggi terdapat pada perlakuan m1p0, sedangkan kandungan $\mathrm{N}$ jaringan terendah terdapat perlakuan $\mathrm{m} 0 \mathrm{p} 1, \mathrm{~m} 0 \mathrm{p} 2$ dan m3p1. Hasanudin (2003) dalam penelitiannya membuktikan bahwa mikoriza dengan bantuan miseliumnya mampu memperluas jangkauan perakaran tanaman, sehingga dapat meningkatkan serapan hara bagi tanaman khususnya hara $\mathrm{P}$ dan $\mathrm{N}$. selanjutnya Hardiatmi (2008) menunjukkan pengaruh yang terlihat karena adanya mikoriza pada tanaman pinus. Benang-benang miselia yang menempel pada akar pinus, mampu menambah daya serap akar terhadap hara P sampai $23 \%$, K bertambah $86 \%$ dan $\mathrm{N}$ $75 \%$ dengan adanya hal tersebut dapat meningkatkan efisiensi pemupukan. Selanjutnya Winarso (2005) membuktikan bahwa pemberian peningkatan dosis pemupukan $\mathrm{N}$ di dalam tanah secara langsung dapat meningkatkan kadar protein ( $\mathrm{N}$ organik) dan produksi tanaman jagung

\section{P Jaringan Tanaman}

Berdasarkan data hasil penelitian, terlihat adanya pengaruh nyata mikoriza dan pupuk NPK terhadap serapan P tanaman. Secara umum, semua perlakuan mikoriza dan NPK memperlihatkan kadar $\mathrm{P}$ jaringan tanaman relatif lebih tinggi dibanding perlakuan tanpa mikoriza. Pada perlakuan tanpa mikoriza dan pupuk NPK, kandungan $\mathrm{P}$ jaringan terendah $50,62 \%$ terdapat pada perlakuan m0p0 (tanpa mikoriza dan tanpa pupuk) sedangkan kandungan $\mathrm{P}$ tanaman tertinggi pada perlakuan m0p3 (tanpa 
Yovita: Peningkatan ketersediaan dan serapan NPK serta hasil tanaman jagung Bisi-16 melalui inokulasi mikoriza dan pupuk NPK pada Alfisol

mikoriza dan $75 \%$ NPK) yang tidak berbeda nyata dengan perlakuan m0p4 (tanpa mikoriza dan $100 \%$ NPK).

Hasil tersebut berkaitan dengan kemungkinan karena adanya kesesuaian (kompatabilitas) antara inokulasi mikoriza dengan tingkat pemupukan fosfat. Seperti diketahui bahwa inokulasi mikoriza dapat meningkatkan serapan $\mathrm{P}$ oleh tanaman, karena mikoriza dengan hifa eksternal, selain dapat memperluas jangkauan rambut akar yang berarti memperluas daerah penyerapan, juga dapat menembus daerah dengan jumlah hara yang rendah (zone of nutrient depletion) yang terdapat disekitar perakaran dan menyerap unsur hara dari daerah tersebut (Zulaikha dan Gunawan, 2006). Akar yang tidak terinfeksi mikoriza tidak dapat menjangkaunya walaupun dengan rambut-rambut akar yang banyak. Hal ini karena diameter hifa mikoiza yang relatif kecil (rata-rata berukuran 2-5 $\mu \mathrm{m}$ ) sehingga mudah menerobos pori-pori tanah yang tidak dapat ditembus oleh rambur-rambut akar (Bethlenfalvay and Linderman, 1992 dalam Zulaikha dan Gunawan, 2006).

Mikoriza juga menghasilkan enzim fosfatase yang mampu mengkatalis hidrolisis komplek fosfat tidak larut yang terdapat di dalam tanah menjadi bentuk fosfat larut yang tersedia bagi tanaman (Fakuara dan Setiadi, 1990 dalam Niswati, dkk, 1996). Selanjutnya fosfat larut ini akan dengan cepat diserap oleh hifa eksternal mikoriza dan kemudian di transfer ke tanaman inang. Dengan demikian tanaman yang diinokulasi mikoriza mempunyai kemampuan untuk menyerap fosfat yang terikat dalam tanah dan fosfat dari pupuk kimia (Manske, 1998 dalam Zulaikha dan Gunawan, 2006),, sehingga penyerapan $P$ menjadi lebih besar dibanding tanaman yang tidak diinokulasi mikoriza.

\section{K Jaringan Tanaman}

Data hasil penelitian untuk $\mathrm{K}$ tanaman terlihat bahwa perlakuan tanpa mikoriza dan pupuk NPK, menghasilkan kandungan $\mathrm{K}$ jaringan tanaman terendah 0,92 \% pada perlakuan m0p0 (tanpa mikoriza dan tanpa pupuk) sedangkan rerata tertinggi $1,68 \%$ pada perlakuan m0p3 (tanpa mikoriza dan 75\% NPK) yang tidak berbeda nyata dengan perlakuan m0p4 (tanpa mikoriza dan $100 \%$ NPK) yaitu $1,54 \%$. 
Yovita: Peningkatan ketersediaan dan serapan NPK serta hasil tanaman jagung Bisi-16 melalui inokulasi mikoriza dan pupuk NPK pada Alfisol

Meningkatnya serapan $\mathrm{K}$ oleh tanaman akibat dukungan mikoriza akan meningkatkan fisiologis tanaman seperti dalam proses respirasi dan fotosintesis sehingga dapat meningkatkan akumulasi karbohidrat dalam proses pembelahan sel dalam pertumbuhan. Hifa yang berperan sebagai sistem perakaran dapat memperpanjang jangkauan penyerapan mencapai $80 \quad \mathrm{~mm}$ dengan laju penyerapannya 6 kali lebih cepat dibandingkan tanaman tanpa mikoriza(Kartini, 1997 dalam Tirta, 2006). Meningkatnya ketahanan terhadap kekeringan pada tanaman bermikoriza juga sebagai akibat tidak langsung membaiknya kandungan hara $\mathrm{P}$ serta kandungan $\mathrm{K}$ yang dikenal berperan penting dalam pengaturan air dalam tanaman (Baon, 1997 dalam Bako, dkk, 2009).

\section{Bobot Kering Tanaman}

Secara umum dapat dilihat dari nilai bobot kering tanaman jagung sebagai tanaman inang, untuk setiap aplikasi tanpa mikoriza dan dosis pupuk NPK menunjukkan perlakuan menghasilkan bobot kering tanaman terendah pada perlakuan m0p0 (tanpa mikoriza dan tanpa pupuk), m0p1(tanpa mikoriza dan 25\% NPK), m0p2(tanpa mikoriza dan 50\% NPK, yaitu masingmasing 21,41 g, 26,74 g, 29,03 g, sedangkan bobot kering tanaman tertinggi 58,37 g pada perlakuan m0p4 (tanpa mikoriza dan 100\% NPK).

Pada perlakuan mikoriza dan pupuk NPK menunjukkan bobot kering tanaman terendah 50,77 g pada perlakuan m2p4 (mikoriza dan $100 \%$ NPK), sedangkan bobot kering tanaman tertinggi 88,57 $\mathrm{g}$ pada perlakuan m1p2 (mikoriza dan 50\% NPK). Foth (1998) dalam Reni Maryeni, dkk (2008) menyatakan bahwa mikoriza dapat meningkatkan penyerapan unsur hara dan air dari dalam tanah yang akan memungkinkan tanaman menghasilkan sel-sel baru dan menghasilkan hormonhormon pertumbuhan kemudian akan mampu memperbanyak batang atau cabang. Hormon pertumbuhan yang dihasilkan antara lain auksin (berfungsi mencegah penuaan akar, sehingga akar dapat berfungsi lebih lama) dan giberelin (merangsang pembesaran dan pembelahan sel. Tanaan yang bermikoriza dapat tumbuh lebih baik karena dapat mengambil unsur hara N,P, K,

\section{Bobot Biji Pipilan Kering}


Yovita: Peningkatan ketersediaan dan serapan NPK serta hasil tanaman jagung Bisi-16 melalui inokulasi mikoriza dan pupuk NPK pada Alfisol

Berdasarkan hasil analisis varians menunjukkan pada perlakuan tanpa mikoriza dan pupuk NPK, rerata terendah 10,77 g terdapat pada perlakuan m0p0 (tanpa mikoriza dan tanpa pupuk), sedangkan rerata tertinggi 17,60 g pada perlakuan m0p4 (tanpa mikoriza dan $100 \%$ NPK).

Perlakuan mikoriza dan pupuk NPK menghasilkan bobot biji pipilan kering terendah 14,80 g pada perlakuan m1p0 (mikoriza dan 25\% NPK). Bobot kering tanaman tertinggi 39,93 g pada perlakuan m3p2. Gambaran ini memperlihatkan bahwa pemberian pupuk saja tidak menjamin peningkatan hasil. Pemberian mikoriza dan NPK memberikan hasil pipilan kering jagung yang terbanyak. Lebih tingginya bobot kering biji pada perlakuan mikoriza dan dosis pupuk NPK karena mikoriza melalui hifanya dapat meningkatkan penyerapan dan unsur hara sehingga dapat memenuhi kebutuhan tanaman dalam memenuhi proses fisiologisnya terutama dalam proses pembentukan dan penyusunan biji yang akhirnya meningkatkan bobot kering biji. Winarso (2005) menyatakan bahwa hara yang paling berperan dalam pembentukan biji dan meningkatkan kualitas biji adalah
P. Selain unsur $P$, pertumbuhan dan perkembangan tanaman hingga sampai biji juga membutuhkan unsur hara $\mathrm{N}$ dan K. Dapat dilihat bahwa dengan meningkatnya ketersediaan NPK bagi tanaman akan mendukung pertumbuhan dan perkembangan tanaman terutama untuk pembentukan dan penyusunan kandungan biji dapat terpenuhi.

\section{Perhitungan Dosis Optimum Pupuk} NPK Tanpa dan Dengan Mikoriza

Perhitungan dosis optimim menunjukkan hasil polynomial orthogonal m0 (tanpa mikoriza) dan NPK dinyatakan bahwa dosis optimum terhadap bobot biji pipilan kering memberikan pengaruh linear. Hal ini disebabkan karena semakin tinggi jumlah pupuk yang diberikan akan diikuti oleh peningkatan bobot biji jagung. Dosis optimum belum dapat tercapai dengan pemberian pupuk hingga 100\% dikarenakan, NPK yang ada di dalam tanah tidak dapat diserap semuanya oleh tanaman (Winarso, 2005). Jadi, tanaman jagung yang tidak diberikan mikoriza ini membutuhkan pupuk dengan dosis melebihi $100 \%$ dosis pupuk yang diberikan untuk dapat mencapai dosis optimum. 
Yovita: Peningkatan ketersediaan dan serapan NPK serta hasil tanaman jagung Bisi-16 melalui inokulasi mikoriza dan pupuk NPK pada Alfisol

Perhitungan dosis optimum lainnya, yaitu hubungan antara dosis NPK dan bobot biji masing-masing dalam suasana m1 (mikoriza asal rhizosfer tanaman jagung) m2 (mikoriza asal rhizosfer tanaman ubi kayu) dan $\mathrm{m} 3$ (mikoriza Serpong) menunjukkan bahwa dosis optimum dicapai pada takaran 50,66\% dari rekomendasi pupuk NPK $(75,99$ $\mathrm{kg} / \mathrm{ha}$ urea, $25,33 \mathrm{~kg} / \mathrm{ha} \mathrm{SP}-36$ dan $\mathrm{kcl}$ ) atau setara dengan $0,38 \mathrm{~g} /$ polybag urea dan 0,31 g/polybag SP-36 dan $\mathrm{kcl}$ ), 45,11\% dari rekomendasi pupuk NPK $(67,66 \mathrm{~kg} / \mathrm{ha}$ urea, $22,55 \mathrm{~kg} / \mathrm{ha} \mathrm{SP}-36$ dan $\mathrm{kcl})$ atau setara dengan 0,34 gr/polybag urea dan 0,28 gr/polybag SP-36 dan $\mathrm{kcl}$,dan 46,10\% dari rekomendasi pupuk NPK $(69,15 \mathrm{~g} / \mathrm{ha}$ urea dan 23,05 SP-36 dan $\mathrm{kcl}$ ) atau setara dengan 0,34 gr/polybag urea dan 0,28 gr/polybag SP36 dan kcl. Apabila dilihat dari hasil dosis optimum yang didapat dari masingmasing jenis mikoriza,maka mikoriza indigen pulau Timor (mikoriza asal rhizosfer tanaman jagung) mempunyai dosis optimum lebih rendah yaitu $45,11 \%$ dibandingkan mikoriza eksogen (Serpong) yaitu 46,10\%. Hal ini Seperti yang dinyatakan oleh Sagin Junior \& Da Silva (2006) dalam Novriani dan Madjid
(2009) bahwa kemampuan spesies CMA dalam hal memberi dampak terhadap tanaman inangnya dipengaruhi oleh kemampuan adaptasinya.

Pemberian pupuk pada tingkat rekomendasi yang lebih tinggi, rata-rata memberikan tingkat efisiensi yang lebih rendah. Sebaliknya dengan pemberian pupuk yang lebih rendah rata-rata memberikan tingkat efisiensi yang lebih tinggi. Pada perlakuan kombinasi mikoriza dan NPK untuk semua variabel tersebut menunjukkan terjadi peningkatan pada semua variabel, namun pada perlakuan kombinasi mikoriza dan NPK pada dosis $75 \%$ masing-masing nilai variabel mengalami penurunan. Faktor pengaruh mikoriza dan NPK secara nyata meningkatkan variabel-variabel tersebut jika dibandingkan pada kombinasi tanpa mikoriza dan pupuk NPK.

\section{SIMPULAN}

1. Inokulasi mikoriza dan dosis pupuk NPK mampu meningkatkan ketersediaan NPK tanah, NPK jaringan tanaman, bobot kering tanaman dan bobot biji pipilan kering. Pada perlakuan inokulasi mikoriza dan NPK untuk semua variabel tersebut menunjukkan 
Yovita: Peningkatan ketersediaan dan serapan NPK serta hasil tanaman jagung Bisi-16 melalui inokulasi mikoriza dan pupuk NPK pada Alfisol

terjadi peningkatan pada semua variabel, namun inokulasi mikoriza dan NPK pada dosis $75 \%$ masingmasing nilai variabel mengalami penurunan. Faktor pengaruh mikoriza dan NPK secara nyata meningkatkan variabel-variabel tersebut jika dibandingkan pada tanpa mikoriza dan pupuk NPK.

2. Dosis optimum pemupukan inokulasi mikoriza $(\mathrm{m} 1, \mathrm{~m} 2$ dan m3) dan dosis pupuk NPK masingmasing terdapat pada dosis pupuk $50,66 \%$ dari rekomendasi pupuk NPK $\left(75,99 \mathrm{~kg}^{-1}\right.$ ha urea, $25,33 \mathrm{~kg}$ ha $^{-1}$ SP-36 dan $\mathrm{KCl}$ ) atau setara dengan 0,38 g/polybag urea dan 0,31 g/polybag SP-36 dan $\mathrm{KCl}$ ), $45,11 \%$ dari rekomendasi pupuk NPK $\left(67,66 \mathrm{~kg} \mathrm{ha}^{-1}\right.$ urea, 22,55 kg ha $^{-1} \mathrm{SP}-36$ dan $\left.\mathrm{KCl}\right)$ atau setara dengan 0,34 g/polybag urea dan 0,28 g/polybag SP-36 dan $\mathrm{KCl}$,dan $46,10 \%$ dari rekomendasi pupuk NPK $\left(69,15 \mathrm{~kg} \mathrm{ha}^{-1}\right.$ urea dan 23,05 SP-36 kg ha ${ }^{-1}$ dan $\mathrm{KCl}$ ) atau setara dengan 0,34 g/polybag urea dan 0,28 g/polybag SP-36 dan $\mathrm{KCl}$. Hasil dosis optimum yang dicapai pada perlakuan kombinasi mikoriza dan NPK ternyata menunjukkan dosis optimum terendah pada perlakuan mikoriza indigen jika dibandingkan mikoriza eksogen. Pada perlakuan tanpa mikoriza $(\mathrm{m} 0)$ memberikan pengaruh linear, yaitu tidak adanya dosis optimum. tanaman jagung yang tidak diberikan mikoriza ini membutuhkan pupuk dengan dosis melebihi $100 \%$ dosis pupuk yang diberikan untuk dapat mencapai dosis optimum.

\section{Ucapan Terima Kasih}

Pada kesempatan ini penulis ingin mengucapkan terima kasih kepada semua pihak yang telah membantu dengan caranya masing-masing dalam melengkapi tulisan ini.

\section{DAFTAR PUSTAKA}

Adu Tae, S., L. Ishaq dan M. Airtur. 2008. Eksplorasi Endomikoriza Indigen potensial dari Rhizosfer Berbagai Tanaman Semi Ringkai Pulau Timor sebagai Agensia Pupuk Hayati. Fakultas Pertanian UNDANA, Kupang.

Badan Pusat Statistik, 2001. Statistik Indonesia. BPS, NTT.

Bako, P, Pollo, R, Airtur, M, 2009. Koleksi dan Aplikasi Isolat Mikoriza Indigen Pada Lahan Kering di Pulau Timor Dalam Upaya Peningkatan Efisiensi Penggunaan Air, Serapan Hara dan 
Yovita: Peningkatan ketersediaan dan serapan NPK serta hasil tanaman jagung Bisi-16 melalui inokulasi mikoriza dan pupuk NPK pada Alfisol

Hasil Tanaman Jagung. Universitas Nusa Cendana. Kupang.

Buntan, A, Bachrein, S, Rauf, M, Soenartiningsih, Suarni, 1997. Interaksi P dan Karbohidrat Terhadap Pembentukan Kolonisasi Mikoriza pada Tanaman Jagung. Balai Pengkajian Teknologi Pertanian. Lembang.

Duaja, W, 2006. Upaya Pengembangan Penerapan Teknologi Di Provinsi NTT. Makalah disampaikan dalam temu teknologi Mikoriza tingkat Provinsi NTT, Tanggal 8-10 Nopember Di Hotel Gadjah Mada Kupang.

Forum Kawasan Timur Indonesia (FKTI). 2008. Seri Sumberdaya Alam; Sektor Pertanian Tanaman Pangan, Perkebunan dan Kehutanan dalam Rangka Menunjang kehidupan Masyarakat KTI. http://forum.easternindonesia.org. 26 Mei 2009.

Hardjowigeno, 2003. Ilmu Tanah. Akademika Pressindo, Jakarta.

Hardiatmi, 2008. Pemanfaatan Jasad Renik mikoriza Untuk Memacu Pertumbuhan Tanaman Hutan. Jurnal Inovasi pertanian Vol. 7, No. 1.

Hasanudin, 2003. Peningkatan Ketersediaan dan Serapan N dan P serta Hasil Tanaman Jagung melalui Inokulasi Mikoriza, Azotobakter dan Bahan Organik pada Ultisol. Jurnal Pertanian, Universitas Bengkulu.

Kasim, 2005. Peran Mikoriza Terhadap Pertumbuhan dan Hasil Tanaman. Makalah Karya Ilmiah Faperta Undana, Kupang.

Karti, 2007. Efektivitas Asam Humik Dan Cendawan Mikoriza Arbuskula Pada Pertumbuhan Kelapa Sawit
Tahap Pembibitan Skala Komersial. Jurnal inovasi Pertanian.

Munir. 1996. Tanah-Tanah Utama di Indonesia. Karakteristik, klasifikasi dan pemanfaatannya. Pustaka Jaya, Jakarta.

Musfal, 2008. Efektifitas Cendawan Mikoriza Terhadap Pemberian Pupuk Spesifik Lokasi Tanaman Jagung Pada Tanah Inceptisol. Universitas Sumatera Utara, Medan.

Nahak, Y. 2002. Pengaruh Mikoriza Vesicular Arbuskular dan pupuk Organik Bokasi Terhadap Pertumbuhan dan Hail Kedelei pada Vertisol. (Tesis). Denpasar. Universitas Udayana.

Najiyati, S. 1992. Palawija Budidaya dan Analisis Usaha Tani. Penebar swadaya. Jakarta.

Niswati, A., S. G., Nugroho, M. U, dan Suryadi, 1996. Pemanfaatan Vesikula arbuskula Untuk Mengatasi Pertumbuhan Tanaman Jagung Akibat Cekaman Kekeringan. Jurnal Tanah Tropika.

Novizan, 2002. Petunjuk Pemupukan Yang Efekif. Agromedia Pustaka, Jakarta.

Novriani dan Madjid. 2009. Peran dan Prospek Mikoriza. http://phosphateindo.com/article/13 157/peran-dan-prospekmikoriza.html. 17 Desember 2009.

Nuhamara, S.T. 1994. Peranan Mikoriza untuk Reklamasi Lahan Kritis. Program Pelatihan Biologi dan Bioteknologi Mikoriza.

Octaviani .N, 2009. Pemanfaatan Cendawan Mikoriza Arbuskular (CMA) Sebagai Pupuk Hayati Untuk Meningkatkan Produksi Pertanian. 
Yovita: Peningkatan ketersediaan dan serapan NPK serta hasil tanaman jagung Bisi-16 melalui inokulasi mikoriza dan pupuk NPK pada Alfisol

http://uwityangyoyo.wordpress.com/2009

/04/05/pemanfaatan-cendawanmikoriza-arbuskular-cma-sebagaipupuk-hayati-untuk-meningkatkanproduksi-pertanian/ Akses tanggal 24 - Juli - 2009. 18.06 PM.

Poerwidodo, 1993. Telaah Kesuburan Tanah. Angkasa. Bandung.

Santoso. E. 2006. Aplikasi Mikoriza Untuk Meningkatkan Kegiatan Rehabilitasi Hutan Dan Lahan Terdegradasi. Makalah Utama Pada Ekspose Hasil-Hasil Penelitian : Konservasi Dan Rehabilitasi Sumberdaya Hutan. Padang, 20 September 2006.

Sasli, W. 2004. Peranan Mikoriza Vesikula Arbuskula (MVA) Dalam Peningkatan Resistensi Tanaman Terhadap Cekaman Kekeringan. Makalah Pribadi,Institut Pertanian Bogor.

Subiksa, I, G, 2009. Pemanfaatan Mikoriza Untuk Penanggulangan Lahan Kritis. (Makalah Falsafah Sains). Pasca sarjana/S3 Institut Pertanian Bogor.

Tirta, I G. 2006. Pengaruh Kalium dan Mikoriza Terhadap Pertumbuhan dan Bibit Panili (Vanilla Planifolia Andrew). Jurnal Biodiversitas Vol. 7. No. 2. Halaman $171-174$.

Winarso, S. 2005. Kesuburan Tanah Kesehatan dan Kualitas Tanah. Gava Media, Yogyakarta.

Widiastuti, H, 2002. Optimasi Simbiosis Cendawan Mikoriza Arbuskula Acaulospora tuberculuta dan Gigaspora margita pada bibit kepala sawit di tanah masam. Jurnal Pertanian.

Yitnosumarto, S. 1993. Perancangan Percobaan Analisis dan Interpretasinya. Gramedia Pustaka Utama, Jakarta.
Zulaikha, S dan Gunawan, 2006. Serapan Fosfat dan Respon Fisiologis Tanaman Cabai Merah Cultivar Hot Beauty Terhadap Mikoriza dan Pupuk Fosfat Pada Tanah Ultisol. www.unlam.ac.id/bioscientiaea/. 